\title{
POTENTIALS OF BIOGAS PRODUCTION FROM YOUNG BULLS MANURE FED WITH DIFFERENT DIETS
}

\section{MÔNICA S. S. DE M. COSTA ${ }^{1}$, LUIZ A. DE M. COSTA ${ }^{2}$, JORGE DE LUCAS JUNIOR ${ }^{3}$, LAÉRCIO A. PIVETTA ${ }^{4}$}

\begin{abstract}
Physical and chemical characteristics of manure are modified by different animal production systems. In cattle feeding system for young bulls there is an inversion of the proportion between forage and concentrate. In other words, the animals receive a smaller amount of forage compared to the traditional system. These changes in the manure characteristics involve changes in the treatment systems. The aim of this study was to determine the potential production of biogas of batch digesters fed with manure from young bulls that received two diets containing different proportions between forage and concentrate, with or without inoculums and submitted to three levels of temperature $\left(25,35\right.$ and $\left.40^{\circ} \mathrm{C}\right)$. The evaluated parameters were total solids (TS) and volatile solids (VS) reduction and biogas potentials production. The digesters fed with manure from animals that received the diet $2(80 \% \mathrm{C}+20 \% \mathrm{R})$ showed the largest reductions of TS and VS. About the potentials of biogas production there was interaction between the factors diet and inoculums, but no effects of temperatures. The treatment content manure from animals fed with diet 2 without inoculums presented the greatest potential of biogas production per $\mathrm{kg}$ of $\mathrm{TS}$ added $\left(0.2123 \mathrm{~m}^{3}\right)$.
\end{abstract}

KEYWORDS: batch digesters, temperature levels, inoculums.

\section{POTENCIAIS DE PRODUÇÃO DE BIOGÁS DE DEJETOS DE NOVILHOS SUPERPRECOCES ALIMENTADOS COM DIFERENTES DIETAS}

RESUMO: Os diferentes sistemas de criação animal no modelo industrial promovem alterações físicas e químicas nas dejeções. Na engorda de bovinos no modelo de confinamento para novilhos superprecoces, tem-se uma inversão na proporção entre volumoso (V) e concentrado (C), ou seja, os animais recebem quantidade inferior de volumoso quando comparado ao sistema tradicional de confinamento, o que implica modificações das dejeções e, consequentemente, no sistema de tratamento utilizado. Neste trabalho, objetivou-se determinar os potenciais de produção de biogás em biodigestores de bancada operados no sistema batelada, alimentados com dejetos de novilhos superprecoces que receberam duas dietas diferenciadas pelas proporções entre $\mathrm{V}$ e $\mathrm{C}$, contendo ou não inóculo na composição do substrato e submetidos a três níveis de temperatura $\left(25^{\circ}, 35^{\circ}\right.$ e $40^{\circ}$ C). Os parâmetros avaliados foram: redução de sólidos totais (ST), redução de sólidos voláteis (SV) e potencial de produção de biogás. Os biodigestores alimentados com dejetos provenientes de animais que receberam a dieta $2(80 \% \mathrm{C}+20 \% \mathrm{~V})$, apresentaram as maiores reduções de ST e SV. Quanto aos potenciais de produção de biogás, houve interação entre os fatores dieta e inóculo, porém não se observou efeito da temperatura. $\mathrm{O}$ tratamento contendo os dejetos provenientes de animais alimentados com a dieta 2, sem a utilização de inóculo, apresentou o maior potencial de produção de biogás por $\mathrm{kg}$ de ST adicionado $\left(0,2123 \mathrm{~m}^{3}\right)$.

PALAVRAS-CHAVE: biodigestor batelada, níveis de temperatura, inóculo.

\footnotetext{
${ }^{1}$ Professora Adjunta dos cursos de graduação e pós-graduação em Engenharia Agrícola na Universidade Estadual do Oeste do Paraná, UNIOESTE/Campus de Cascavel. mssmc@ig.com.br.

${ }^{2}$ Eng. Agr. Dr. em Energia na Agricultura, Bolsista RHAE/CNPq. lmendo@ig.com.br.

${ }^{3}$ Professor Titular do Departamento de Engenharia Rural da Faculdade de Ciências Agrárias e Veterinárias - FCAV/UNESP, jlucas@fcav.unesp.br.

${ }^{4}$ Doutorando do Programa de Pós Graduação em Agronomia/Agricultura da Faculdade de Ciências Agronômicas - FCA/UNESP, laerciopivetta@fca.unesp.br.

Recebido pelo Conselho Editorial em: 13-12-2011
}

Aprovado pelo Conselho Editorial em: 18-6-2013 


\section{INTRODUCTION}

The potential of methane emissions from different animal waste (cattle, pigs, sheep, goats and poultry) was estimated by ARTHUR \& BIDOO (2011) in four African countries (Nigeria, Ghana, Burkina Faso and Mali), from 1998 to 2008. Of the total $845 \mathrm{Gg}$ of methane emitted by livestock during the study period, $40 \%$ was from cattle manure, followed by the waste of pigs, goats, sheep and poultry which contributed $21.2 \%, 18.7 \%, 13,1 \%$ and $6.6 \%$, respectively. In Brazil, with similar goals, but using data collected "in situ", ORRICO JR. et al. (2011) conducted a experiment comparing the main species of agricultural interest (pigs, cattle, goats, laying hens and broilers), in relation to the conversion efficiency of diets in animal products (meat and egg), the production of waste and potential issuance of Methane. The authors concluded that in general, the waste of ruminants (mainly cattle) showed high levels of fiber and low potential for biogas production, however, the lower performance of these animals in the conversion of food into product and increased production of waste made them submit higher yields of methane per $\mathrm{kg}$ of food ingested.

However, although the Brazilian herd of cattle, both dairy a beef, is significant, there are few references on the energy potential of these wastes in national periodicals in the last five years (2006-2011), may be cited the work by RIBEIRO et al. (2007), GALBIATI et al. (2010), XAVIER \& LUCAS JR. (2010). In the international literature, one can cite an article by Brazilian authors, SALOMON \& LORA (2009) who present a review on estimate of the potential for electricity generation from different sources of biogas in Brazil, including cattle manure. With respect to the potential to generate biogas and methane from cattle manure, also can be cited FANTOZZI \& BURATTI (2009) evaluating the yield and composition of biogas from different substrates, among them the cattle manure, which had, after 33-day retention time, $0.15 \mathrm{Nm} 3$ production of biogas per $\mathrm{kg}$ VS added methane or $0.04 \mathrm{Nm} 3$ per $\mathrm{kg}$ of VS.

The percentage of methane in biogas was $46.5 \%$. The authors also convert biogas into energy and as a result have $0.41 \mathrm{kWh}$ per $\mathrm{kg}$ of VS added. MASSÉ et al. (2011) describe the potential contribution of farms that produce biogas to reduce the emission of greenhouse gases and other environmental impacts related to livestock operations and cite an average production of $0.25 \mathrm{~L}$ biogas per g of VS for waste of cattle and RICO et al. (2011) evaluated the potential of biogas production from manure liquid fraction of dairy cows with retention times ranging from 10 to 20 days and organic loading rates ranging from 2.0 to $4.5 \mathrm{~kg}$ VS per $\mathrm{m}^{3}$ per day. The stable biogas productions were stricken from 0.66 to $1.47 \mathrm{~m}^{3} /\left(\mathrm{m}^{3}\right.$ day) and the authors finish biomethanization commenting that the liquid fraction of the manure of dairy cows in intensive farming has the potential to provide more than $2 \%$ of total electricity in the region of Cantabria - Spain. However, several factors can alter the characteristics of the waste influencing its potential for biogas production, and feeding the animals an important factor in this respect (AMON et al., 2007; JARRET et al., 2011a; JARRET, et al., 2011b). Cattle in feedlot very early are an example of this change. According ARRIGONI (2003), younger steers are animals which immediately after weaning are completed in confinement regime and slaughtered at 15 months of age, with a minimum weight of $450 \mathrm{~kg}$, or over $16 \mathrm{kilos}$. However, to ensure this performance, need to promote significant changes in diet, and this procedure directly affects the quantitative and qualitative characteristics of their stools, which therefore implies modifications in the treatment system used.

To HARDING et al. (2001), the extent of biogas production from cattle manure is dependent on the feeding of animals, since in most cases they consume large amounts of bulky food to be responsible for the generation of larger amounts of substrates structural carbohydrates (cell wall components), which will result in slower production of biogas production and probably will be in smaller amounts. In the case of the confinement system as super class, however, there is an inversion of the forage to concentrate ratio, or intake of food is superior to concentrated forage, which can promote change in the potential production of methane gas. Such changes have been observed by MOLLER et al. (2004), which effected the anaerobic digestion of cattle manure and observed linear increases in biogas production and biogas production potential was reduced as the amount of forage. 
In Brazil, studies on the administration of diets for different ratios of forage and concentrate for ruminant (cattle and goats), varying or not design parameters and their effect on the potential of biogas generation were reported by AMORIM et al. (2004) working with goats fed a diet containing $40 \%$ forage $(\mathrm{F})$ and $60 \%$ concentrate $(\mathrm{C})$ during the four seasons of the year; ORRICO et al. (2007 ) undergoing anaerobic digestion waste generated by Saanen goats in four age categories ( 2 and 4 , 4 and 8,8 and 12 and above 12 months) fed with three diets ( $80 \% \mathrm{~F}+20 \% \mathrm{C} ; 60 \% \mathrm{~F}+40 \% \mathrm{C}$; $40 \% \mathrm{~F}+20 \%$ ); ORRICO JR. et al. (2010) studied the possible changes in the process of anaerobic manure from cattle manure in the finishing phase fed with different proportions of forage : concentrate ( $60 \% \mathrm{~F}+40 \% \mathrm{C}$ and $40 \% \mathrm{~F}+40 \% \mathrm{C}$ ) and different time of hydraulic retention ( 30 , 60 , 90 and 120 days); ORRICO et al . (2011) evaluated the effects of age of Saanen goats (90, 120 and 150 days of age) and diets with the three ratios of forage: concentrate (80:20, 60:40 and 40:60) on the anaerobic digestion of their waste.

The objective of this work was to determine the potential of biogas digesters in bench operated in batch system, fed manure younger steers given two different diets by forage to concentrate ratios with and without the use of inoculums in three levels temperature.

\section{MATERIAL AND METHODS}

The test was conducted in anaerobic digestion at the Anaerobic Digestion Lab, located in the Department of Rural Engineering FCAV / UNESP, Jaboticabal, Brazil.

The statistical design was a completely randomized in a factorial arrangement, consisting of 12 treatments ( 2 diets $\mathrm{x} 3$ temperature levels $\mathrm{x}$ use or not of inoculums) with two replications, totaling 24 digesters bench.

The manure was produced by younger steers receiving two diets that varied the forage: concentrate ratio of $65 \%$ concentrate and $35 \%$ forage (Diet 1) and $80 \%$ concentrate $+20 \%$ forage (Diet 2). In the composition of the diets were used varying amounts of concentrate $(83.5 \%$ crude protein), corn silage (whole plant and wet grain) and pre-dried alfalfa. The composition of manure from each diet is shown in Table 1.

TABLE 1. Characterization of manure that were produced by cattle fed with diets with $65 \%$ of concentrated and $35 \%$ of forage (Diet 1) or $80 \%$ of concentrated and $20 \%$ of forage (Diet 2).

\begin{tabular}{|c|c|c|}
\hline Components & Diet 1 & Diet 2 \\
\hline ST (\%) & 20.01 & 24.22 \\
\hline VS (\%) & 82.66 & 87.04 \\
\hline $\mathrm{N}(\%)$ & 3.1 & 2.5 \\
\hline $\mathrm{FB}(\%)$ & 19.5 & 1.67 \\
\hline FDN $(\%)$ & 51.21 & 40.25 \\
\hline FDA $(\%)$ & 21.02 & 14.16 \\
\hline
\end{tabular}

ST: Total Solids, VS: volatile solids, N: nitrogen, FB: crude fiber, FDN: neutral detergent fiber.FDA: acid detergent fiber.

Three batteries with eight digesters each were used, making a total of 24 digesters with capacity of 10 liters of substrate. Each battery of eight digesters was in a box of cement with a capacity of 500L, insulated wrap through $3 \mathrm{~cm}$ polystyrene (Styrofoam), containing $270 \mathrm{~L}$ of water heated to prescribed temperatures: $40^{\circ} \mathrm{C}, 35^{\circ} \mathrm{C}$ and $25^{\circ} \mathrm{C}$. In each box was installed a heating system by means of electrical resistances of 5,000, 3,000 and 1,000 W and a thermostat control (20 A thermostat) temperature. The homogenization was ensured by the use of water pump $150 \mathrm{~W}$ in each box, which allowed trigger the movement of water when the thermostat was shooting the heating system (SOUZA et al., 2005).

Out of eight digesters of each battery, four were filled with substrate containing manure from animals fed with Diet 1, two with the inoculums and two without inoculums, and the other four with 
manure from animals fed with Diet 2, two with the inoculums and two without inoculums. Defined, therefore four substrates, namely $\mathrm{D}_{1} \mathrm{Ci}$ : diet 1 manure with inoculums; $\mathrm{D}_{1} \mathrm{Si}$ : diet 1 manure without inoculums; $\mathrm{D}_{2} \mathrm{Ci}$ : diet 2 manure with inoculums; $\mathrm{D}_{2} \mathrm{Si}$ : diet 2 manure without inoculums. All treatments were subjected to three levels of temperature: $25^{\circ}, 35^{\circ}$ and $40^{\circ} \mathrm{C}$. Each digester had a gasometer independently sized to store $15 \mathrm{~L}$ of biogas built in reduced scale, whose purpose is to store and allow quantification of the produced biogas through a graduated scale displayed on the outside. All gasometers are dipped in a cement box of 1000 liter capacity, containing approximately $750 \mathrm{~L}$ of water and a blade $5 \mathrm{~mm}$ hydraulic oil, which allows to maintain the tightness of biogas and to prevent the absorption of CO2 produced ( MIRANDA 2009).

The composition of the charge is use of digesters where inoculums consisted of $2.0 \mathrm{~kg}$ of manure + biofertilizer $1.5 \mathrm{~kg}$ of bovine origin (inoculums) +4.5 liters of water, totaling 8.0 liters of substrate in each digester. For the treatment without inoculums, the load of the digester consisted of $2.4 \mathrm{~kg}$ of manure +5.6 liters of water. The inoculums used for charging the digesters showed $\mathrm{pH}=$ 7.27, $\mathrm{ST}=5.23 \%$ and $\mathrm{VS}=74.90 \%$.

With the initial loading (starting) described above, the digesters were monitored for 84 days.

The levels of ST and VS evaluated in the influent and effluent of batch digesters bench were determined using methods described by APHA/AWWA/WEF (2005).

The biogas production was determined by measuring the vertical displacement of gasometers and multiplying by the cross-sectional area of the internal gasometers, or $0.030887 \mathrm{~m}^{2}$. After each reading the gasometers were zeroed using the record discharge of biogas. The correction of the volume of biogas for the conditions of 1 atm. and $20^{\circ} \mathrm{C}$ was made based on the work of CAETANO (1985).

The potential for biogas production was estimated using production data and daily quantities of manure "in nature" of substrate, total solids and volatile solids in the digesters added, the low amount of volatile solids in the process of anaerobic digestion. Data were subjected to analysis of variance and when significant, used the test averages (for temperature).

\section{RESULTS AND DISCUSSION}

The average levels of total and volatile solids, and percentage mass at the beginning and end of the process of anaerobic digestion, as well as reductions of ST and VS are presented in Table 2.

TABLE 2. Total solids and volatile solids in percentage, mass and reduction in total and volatile solids for both diets analyzed, with (C) and without (S) the inoculums (I- initial and Ffinal).

\begin{tabular}{|c|c|c|c|c|c|c|c|c|c|c|}
\hline \multirow[t]{3}{*}{ Tratamentos } & \multicolumn{4}{|c|}{ ST } & \multirow{3}{*}{$\begin{array}{c}\text { Reduction } \\
\text { ST } \\
\% \\
\end{array}$} & \multicolumn{4}{|c|}{ VS } & \multirow{3}{*}{$\begin{array}{c}\text { Reduction } \\
\text { VS } \\
\% \\
\end{array}$} \\
\hline & \multicolumn{2}{|c|}{$\%$} & \multicolumn{2}{|c|}{$\mathrm{Kg}$} & & \multicolumn{2}{|c|}{$\%$} & \multicolumn{2}{|c|}{$\mathrm{Kg}$} & \\
\hline & I & $\mathrm{F}$ & $\mathrm{I}$ & $\mathrm{F}$ & & I & $\mathrm{F}$ & $\mathrm{I}$ & $\mathrm{F}$ & \\
\hline $\mathrm{D}_{1} \mathrm{Ci}$ & 4.57 & 3.79 & 0.366 & 0.303 & 17.07 & 3.63 & 2.846 & 0.29 & 0.23 & 21.6 \\
\hline $\mathrm{D}_{1} \mathrm{Si}$ & 4.15 & 3.11 & 0.332 & 0.249 & 25.06 & 3.49 & 2.742 & 0.28 & 0.22 & 21.4 \\
\hline $\mathrm{D}_{2} \mathrm{Ci}$ & 1.78 & 1.18 & 0.142 & 0.094 & 33.70 & 1.48 & 0.959 & 0.12 & 0.077 & 35.2 \\
\hline $\mathrm{D}_{2} \mathrm{Si}$ & 2.51 & 1.66 & 0.201 & 0.133 & 33.90 & 2.18 & 1.412 & 0.17 & 0.113 & 35.2 \\
\hline
\end{tabular}

Diet 1: $65 \%$ concentrate $+35 \%$ forage; Diet $2: 80 \%$ concentrate $+20 \%$ forage

ORRICO JR. et al. (2010) working with the anaerobic digestion of manure from cattle fed diets differentiated by levels of concentrate and forage $(40 \% \mathrm{~F}+60 \% \mathrm{C}$ and $60 \% \mathrm{~F}+40 \% \mathrm{C})$, also observed greater reductions in ST and VS in the diet richer in concentrated $(40 \% \mathrm{~F}+60 \% \mathrm{C})$, independent of hydraulic retention time (HRT). The authors justify this result based on lower levels of fibrous constituents (neutral detergent fiber and acid detergent fiber) presented in smaller 
amounts might have favored the greater reductions in ST and VS. Similar values were also presented by ORRICO et al. (2011) working with the anaerobic digestion of manure from Saanen goats fed with different diets with forage and concentrate. The authors found that the mean reductions of VS were lower $(\mathrm{p}<0.05)$ when it made the anaerobic digestion of substrates produced with the stool of animals fed by $80 \% \mathrm{~F}+20 \% \mathrm{C}$ (average $28.34 \%$ ), in relation to the substrates produced from the stool of animals fed with diets $60 \% \mathrm{~F}+\mathrm{C} 40 \%$ (mean $31.77 \%$ ), which were lower than the reductions obtained in the substrates prepared with the stool of animals fed with $40 \%$ $\mathrm{F}+60 \% \mathrm{C}$ (mean $34.03 \%$ ), indicating that the stool produced from diets containing higher amounts of concentrate, when subjected to the process of anaerobic digestion, presented higher degradability than those produced from diets with low amount of concentrate.

The effect of the diets, the use of the inoculums and temperatures in the potential of biogas production can be viewed by the summary of the analysis of variance of the potential of biogas per $\mathrm{kg}$ of substrate (SUBST) per $\mathrm{kg}$ of total solids added (STADIC) per $\mathrm{kg}$ of volatile solids added (VSADIC) per kg of low volatile solid (VSRED) and per $\mathrm{kg}$ of manure (STOOL), shown in Table3.

TABLE 3. Summary of the analysis of variance (F values) of the potential of biogas per $\mathrm{kg}$ of substrate (SUBST) per $\mathrm{kg}$ of solids added (STADIC) per $\mathrm{kg}$ of volatile solids added (VSADIC) per $\mathrm{kg}$ of low volatile solids (VSRED) per $\mathrm{kg}$ of manure (MUCK), depending on the different diets (D), substrate temperatures (T) and use or not of inoculums (I).

\begin{tabular}{lccccc}
\hline Source of. Variation & SUBST & STADIC & VSADIC & VSRED & MUCK \\
\hline Diet. (D) & $11.24^{* *}$ & $92.76^{* *}$ & $87.90^{* *}$ & $22.39^{* *}$ & $9.87^{* *}$ \\
Inoculums (I) & $30.92^{* *}$ & $24.93^{* *}$ & $23.10^{* *}$ & $20.64^{* *}$ & $16.45^{* *}$ \\
Temperature (T) & $3.02^{\mathrm{ns}}$ & $2.36^{\mathrm{ns}}$ & $2.36^{\mathrm{ns}}$ & $2.84^{\mathrm{ns}}$ & $2.81^{\mathrm{ns}}$ \\
D x I & $6.98^{*}$ & $5.42^{*}$ & $5.82^{*}$ & $3.05^{\mathrm{ns}}$ & $5.62^{*}$ \\
D x T & $1.85^{\mathrm{ns}}$ & $1.12^{\mathrm{ns}}$ & $1.16^{\mathrm{ns}}$ & $1.68^{\mathrm{ns}}$ & $1.86^{\mathrm{ns}}$ \\
I x T & $2.54^{\mathrm{ns}}$ & $2.85^{\mathrm{ns}}$ & $2.80^{\mathrm{ns}}$ & $2.56^{\mathrm{ns}}$ & $2.0^{\mathrm{ns}}$ \\
D x I x T & $0.01^{\mathrm{ns}}$ & $0.26^{\mathrm{ns}}$ & $0.23^{\mathrm{ns}}$ & $0.02^{\mathrm{ns}}$ & $0.00^{\mathrm{ns}}$ \\
\hline CV $(\%)$ & 28.74 & 24.57 & 24.72 & 27.39 & 29.30 \\
\hline
\end{tabular}

ns: not significant, $*$ significant at $5 \%, * *$ significant at $1 \%$.

It can be observed by analysis of variance, the influence of diet and inoculums on biogas production ( $\mathrm{p}<0.01)$, but no significant effect of temperature on the process. It is also observed significant interaction $(\mathrm{p}<0.05)$ between the two diets tested and inoculums potential at all, except the potential of biogas per $\mathrm{kg}$ VS reduced. No significant interaction for the factors diet and temperature, inoculums and temperature, nor diet, temperature and inoculums.

In order to facilitate the discussion, in Table 4 one can visualize the average potentials as a function of temperature in Table 5 and average potentials of biogas when adjusted to $20^{\circ} \mathrm{C}$ and 1 atm. considering both diets and whether or not the inoculums.

TABLE 4. Average potentials of biogas production as a function of temperature, corrected to $20^{\circ} \mathrm{C}$ and $1 \mathrm{~atm}$ per $\mathrm{kg}$ of substrate per $\mathrm{kg}$ of total solids and volatile solids added per $\mathrm{kg}$ of reduced volatile solids per $\mathrm{kg}$ of manure.

\begin{tabular}{cccccc}
\hline \multicolumn{5}{c}{$\mathrm{m}^{3}$ of biogas per } \\
\hline Temp $\left({ }^{\circ} \mathrm{C}\right)$ & substratum $\mathrm{kg}$ & $\mathrm{kg}$ de ST added & $\mathrm{kg}$ de VS added & $\mathrm{kg}$ de VS reduced & $\mathrm{kg}$ de manure \\
\hline 25 & 0.033 & 0.1164 & 0.1391 & 0.4852 & 0.0120 \\
35 & 0.0036 & 0.1292 & 0.1537 & 0.5255 & 0.0128 \\
40 & 0.0026 & 0.0986 & 0.1172 & 0.3791 & 0.0091 \\
\hline
\end{tabular}


It can be observed that even where there is no significant difference of temperatures in biogas production, the highest values were found in the digesters that remained in the range of $35^{\circ} \mathrm{C}$. SOUZA et al. (2005) operating the same reactors used in this research, but fed with pig manure in the finishing phase and also evaluating the agitation or not of the substrate, concluded that the agitation did not interfered on the best performance, including less time spent to achieve certain level of biogas production was observed at temperature of $35^{\circ} \mathrm{C}$. CHAE et al. (2008), to evaluate the effect of reactors operated at temperatures in the range from mesophilic temperatures $(25,30$ and $35^{\circ} \mathrm{C}$ ) and fed with swine manure observed that at temperature of $30^{\circ} \mathrm{C}$, the yield of methane was reduced only $3 \%$ compared to $35^{\circ} \mathrm{C}$, while a reduction of $17.4 \%$ was observed when the digestion was carried out at $25^{\circ} \mathrm{C}$. However, the authors conclude, this result does not mean that the higher the temperature the better the performance of production due to increased energy requirement necessary to maintain digestion in high temperatures.

TABLE 5. Average potentials of biogas, corrected to $20^{\circ} \mathrm{C}$ and $1 \mathrm{~atm}$ per $\mathrm{kg}$ of substrate, per $\mathrm{kg}$ of total solids and volatile solids added per $\mathrm{kg}$ and reduced volatile solids per $\mathrm{kg}$ of manure.

\begin{tabular}{|c|c|c|c|c|}
\hline \multirow[t]{5}{*}{ m3 biogas per kg substrate } & \multirow{2}{*}{ Inoculums } & \multicolumn{2}{|c|}{ Diet } & \multirow{2}{*}{ Average } \\
\hline & & 1 & 2 & \\
\hline & with & $0.0020 \mathrm{Aa}$ & $0.0023 \mathrm{Ab}$ & 0.0021 \\
\hline & without & $0.0031 \mathrm{Ba}$ & $0.0053 \mathrm{Aa}$ & 0.0042 \\
\hline & average & 0.0026 & 0.0038 & \\
\hline \multirow[t]{3}{*}{ m3 biogas per $\mathrm{kg}$ of added $\mathrm{ST}$} & with & $0.0440 \mathrm{Ba}$ & $0.1280 \mathrm{Ab}$ & 0.0860 \\
\hline & without & $0.0747 \mathrm{Ba}$ & $0.2123 \mathrm{Aa}$ & 0.1435 \\
\hline & avarage & 0.0593 & 0.1702 & \\
\hline \multirow[t]{3}{*}{$\mathrm{m} 3$ of biogas per $\mathrm{kg}$ of VS added } & with & $0.0555 \mathrm{Ba}$ & $0.1515 \mathrm{Ab}$ & 0.1035 \\
\hline & without & $0.0885 \mathrm{Ba}$ & $0.2511 \mathrm{Aa}$ & 0.1698 \\
\hline & average & 0.0720 & 0.2013 & \\
\hline \multirow[t]{3}{*}{$\mathrm{m} 3$ of biogas per $\mathrm{kg} \mathrm{VS}$ reduced $*$} & with & 0.2682 & 0.4228 & $0.3455 \mathrm{~b}$ \\
\hline & without & 0.4131 & 0,7488 & $0.5809 \mathrm{a}$ \\
\hline & average & $0.3407 \mathrm{~B}$ & $0.5858 \mathrm{~A}$ & \\
\hline \multirow[t]{3}{*}{$\mathrm{m}^{3}$ biogas per $\mathrm{kg}$ of manure } & with & $0.080 \mathrm{Aa}$ & $0.0091 \mathrm{Ab}$ & 0.0086 \\
\hline & without & $0.0103 \mathrm{Ba}$ & $0.0178 \mathrm{Aa}$ & 0.0141 \\
\hline & avarage & 0.0092 & 0.0134 & \\
\hline
\end{tabular}

Means followed by the same letters, uppercase and lowercase letters on the line in the column, do not differ by $\mathrm{F}$ test at $5 \%$ probability. Interaction not significant.

It is noted from Table 5 that the substrates composed of manure from animals fed with diet 2 $(80 \% \mathrm{C}+20 \% \mathrm{~F})$, with or without the use of inoculums exhibited higher biogas potential production compared with the substrate prepared with the manure of animals fed with diet $1(65 \% \mathrm{C}+35 \% \mathrm{~F})$. The greatest potential for biogas generation in manure from animals fed with higher levels of concentrate was also observed by AMORIM et al. (2004) working with two genotypes of goats for which varied the amount of concentrate in the diet. ORRICO JR. et al. (2010) also observed higher biogas production in digesters fed with manure from cattle fed with diets rich in concentrate $(40 \%$ $\mathrm{F}+60 \% \mathrm{C}$ ), when compared with those fed with manure from cattle fed with diets with lower amount of concentrate $(60 \% \mathrm{~F}+40 \% \mathrm{C})$, independent of hydraulic retention time.

We also observed a significant difference, with a negative effect on the use of inoculums and according to analysis of variance (Table 5), there was an interaction between d iet factors and 
inoculums. Thus, in the digesters fed with manure from animals that received a diet richer in protein (diet 2), the inoculums caused a decrease of biogas production. As diet 1 this fact also occurred, although the differences were not significant, it can be inferred that the conditions of this test, the inoculums was not satisfactory, although this result disagrees with other results obtained by other authors who also underwent manure cattle for anaerobic digestion using inoculums (XAVIER \& LUCAS JR., 2010; ZHENG et al., 2010; PANDEY et al., 2011; ZHOU et al., 2011).

This fact can be explained by the type of inoculums used. When using biofertilizer (stabilized material) as inoculums, the mainly function is to provide biomass to start faster the process of anaerobic digestion, thus accelerating the biogas production, as was observed in this assay. However, the usable volume occupies fermentation chamber and therefore in the final calculation, the biogas can be lower when compared to other reactor in which the volume of the substrate to be digested (noninoculumsted) is bigger. This fact was also observed by STEIL (2001) using effluent digester as inoculums in three concentrations $(0,10$ and 15\%) in the anaerobic digestion of manure from poultry cutting, laying hens and pigs. The author noted that although there has been improvement in biogas production, there were no differences between the substrates that received 10 or $15 \%$ of inoculums, with regard to the anticipation of the peak production of biogas, early burning and total production. The author concludes noting that the addition of the inoculums in an amount above the optimum, could occupy a volume that is filled with waste being treated, may lead to bad performance of the system.

\section{CONCLUSION}

The largest potential for biogas production obtained during the test batch ( 84 days) were from the treatment consisting of manure from younger steers fed with diet based on the proportion of $80 \%$ concentrate and $20 \%$ forage, without the use of inoculums regardless of the temperature.

\section{REFERENCES}

AHRING, B. K.; IBRAHIM, A. A.; MLADENOVSKA. Effect of temperature increase from 55 to $65^{\circ} \mathrm{C}$ on performance and microbial population dynamics of an anaerobic reactor treating cattle manure. Water Research, New York, v 35, n. 10, p. 2246-2452, 2001.

\section{AMERICAN PUBLIC HEALTH ASSOCIATION; AMERICAN WATER WORKS ASSOCIATION; WATER ENVIRONMENT FEDERATION - APHA/AWWA/WEF. Standard methods for examination of water and wastewater. 21 th ed. Washington, D.C.: Water Works Association, 2005. 1368p.}

AMON, T.; AMON, B., KRYVORUCHKO, V.; ZOLLITSCH, W.; MAYER, K.; GRUBER, L. Biogas production from maize and dairy cattle manure - Influence of biomass composition on the methane yield. Agriculture, Ecosystems and Environment, Amsterdam, v.118, p.173-182, 2007.

AMORIM, A.C.; LUCAS JÚNIOR, J.; RESENDE, K.T. Biodigestão anaeróbia de dejetos de caprinos obtidos nas diferentes estações do ano. Engenharia Agrícola, Jaboticabal, v.24, n.1, p.1624, 2004.

ARRIGONI, MARIO DE BENI. Eficiência produtiva de bovinos de corte - modelo biológico superprecoce; desenvolvimento de linha de pesquisa. 2003. $428 \mathrm{f}$. Tese (Livre-Docência) Faculdade de Medicina Veterinária e Zootecnia, Universidade Estadual Paulista, Botucatu, 2003.

ARTHUR, R.; BAIDOO, M.F. Harnessing methane generated from livestock manure in Ghana, Nigéria, Mali e Burkina Faso. Biomass and Bioenergy, Oxford, v.35, p. 4648-4656, 2011.

CAETANO, L. Proposição de um sistema modificado para quantificação de biogás. $1985.75 \mathrm{f}$. Dissertação (Mestrado em Agronomia/Energia na Agricultura) - Faculdade de Ciências Agronômicas Universidade Estadual Paulista, Botucatu, 1985. 
CHAE, K.J.; AM JANG.; YIM, S.K.; KIM, S.I. The effects of digestion temperature and temperature shock on the biogas yields from the mesophilic anaerobic digestion of swine manure. Bioresource Technology, Essex, v.99, p. 1-6, 2008.

FANTOZZI, F.; BURATTI, C. Biogas production from different substrates in an experimental Continuously Stirred Tank Reactor anaerobic digester. Bioresource Technology, Essex, v.100, p. 5783-5789, 2009.

GALBIATTI, J.A.; CARAMELO, A.D.; SILVA, F.G.; GERARDI, E.A.B.; CHICONATO, D.A. Estudo qualiquantitativo do biogás produzido por substratos em biodigestores tipo batelada. Revista Brasileira de Engenharia Agrícola e Ambiental, Campina Grande, v.14, n.4, p. 432-37, 2010.

JARRET, G.; COZANNET, P.; MARTINEZ, J.; DOURMAD, J.Y. Effect of different quality wheat dried distiller's grain solubles (DDGS) in pig diets on composition of excreta and methane production from faeces and slurry. Livestock Science, Amsterdam, v.140, n.1-3, p. 275-282, 2011 a.

JARRET, G.; CERISUELO, AL.; PEU, P.; MARTINEZ, J.; DOURMAD, J. Impact of pigs diets with different fibre contents on the composition of excreta and their gaseous emissions and anaerobic digestion. Agriculture, Ecosystems \& Environment, Amsterdam. Disponível em: <http://dx.doi.org/10.1016/j.agee.2011.05.029>. 2011b.

MASSÉ, D.I.; TALBOT, G.; GILBERT, Y. On farm biogas production : a method to reduce GHG emissions and develop more sustainable livestock operations. Animal Feed Science and Technology, Amsterdam, v.166-167, p. 436-445, 2011.

MIRANDA, A.P. Suínos em diferentes fases de crescimento alimentados com milho ou sorgo: desempenho, digestibilidade e efeitos na biodigestão anaeróbia. 2009. $123 \mathrm{f}$. Tese (Doutorado em Zootecnia/Produção Animal) - Faculdade de Ciências Agrárias e Veterinárias, Universidade Estadual Paulista, Jaboticabal, 2009.

MOLLER, H.B.; SOMMER, S.G.; AHRING, B.K. Methane productivity of manure, straw and solid fractions of manure. Biomass Bioenergy, Oxford, v.26, n.3, p.485-495, 2004.

ORRICO JUNIOR., M.A.; ORRICO, A.C.A.; LUCAS JUNIOR., J.de. Influência da relação volumoso:concentrado e do tempo de retenção hidráulica sob a biodigestão anaeróbia de dejetos de bovinos. Engenharia Agrícola, Jaboticabal, v.30, n.3, p.386-394, 2010.

ORRICO JUNIOR, M.A.; ORRICO, A.C.A.; LUCAS JUNIOR, J. de. Produção animal e o meio ambiente: uma comparação entre potencial de emissão de metano dos dejetos e a quantidade de alimento produzido. Engenharia Agrícola, Jaboticabal, v.31, n.2, p.399-410, 2011.

ORRICO, A.C.A.; LUCAS JUNIOR, J.de; ORRICO JUNIOR, M.A.P. Caracterização e biodigestão anaeróbia dos dejetos de caprinos. Engenharia Agrícola, JAobticabal, v.27, n.3, p. 639-647, 2007.

ORRICO, A.C.A.; ORRICO JUNIOR, M.A.P.; LUCAS JUNIOR, Jde. Biodigestão anaeróbia dos dejetos de cabritos Saanen alimentados com dietas com diferentes proporções volumoso e concentrado. Revista Brasileira de Zootecnia, Viçosa-MG, v.40, n.2, p. 448-453, 2011.

PANDEY, P.K.; NDEGWA, P.M.; SOUPIR, M.L.; ALLDREDGE, J.R.; PITTS, M.J. Efficacies of inocula on the startup of anaerobic reactors treating dairy manure under stirred and unstirred conditions. Biomass and Bioenergy, Oxford, v. 35, p. 2705-2720, 2011.

RIBEIRO G.M.; SAMPAIO, A.A.M.; FERNANDES, A.R.M.; HENRIQUE, W.; SUGOHARA, A.; AMORIM, A.C. Efeito da fonte proteica e do processamento físico do concentrado sobre a terminação de bovinos jovens confinados e o impacto ambiental dos dejetos. Revista Brasileira de Zootecnia, Viçosa, MG, v.36, n.6, p.2.082-2.091, 2007.

RICO, C.; RICO, J.L.; TEJERO, I.; MUÑOZ, N.; GÓMEZ, B. Anaerobic digestion of the liquid fraction of dairy manure in pilo plant for biogás production: residual methane yield of digestate. Waste Management, vVienna, .31, p.2167-73, 2011. 
SALOMON, K.R.; LORA, E.E.S. Estimate of the electric energy generating potential for different sources of biogas in Brazil. Biomass and Bioenergy, Oxford, v.33, p. 1101-1107, 2009.

SOUZA, C.F.; LUCAS JUNIOR, J.de.; FERREIRA, W.P.M. Biodigestão anaeróbia de dejetos de suínos sob efeito de três temperaturas e dois níveis de agitação do substrato: considerações sobre a partida. Engenharia Agrícola, Jaboticabal, v.25, n.2 , p. 530-539, 2005.

STEIL, L. Avaliação do uso de inóculos na biodigestão anaeróbia de resíduos de aves de postura, frangos de corte e suínos. 2001. 108f. Dissertação (Mestrado em Biotecnologia), - Instituto de Química, Universidade Estadual Paulista, Araraquara, 2001.

XAVIER, C.de.A.N.; LUCAS JUNIOR, J.de. Parâmetros de dimensionamento para biodigestores batelada operados com dejetos de vacas leiteiras com e sem uso de inoculo. Engenharia Agrícola, Jaboticabal, v.30, n.2, p. 212-223, 2010.

ZENG, S.; YUAN, X.; SHI, X.; QIU, Y. Effect of inoculum/substrate ratio on methane yield and orthophosphate release from anaerobic digestion of Microcystis spp. Journal of Hazardous Materials, v.178, n.1-3, p.89-93, 2010.

ZHOU, Y.; ZHANG, Z.; NAKAMOTO, T.; LI, Y.; YANG, Y.; UTSUMI, M.; SUGIRA, N. Influence of substrate-to-inoculum ratio on the batch anaerobic digestion of bean curd refuse-okara under mesophilic conditions. Biomass and Bioenergy, Oxford, v. 35, n.7, p. 3251-3256, 2011. 